\title{
UJI LC 50 LIMBAH TAHU TERHADAP IKAN NILA (ORECHROMIS NILOTICUS) UMUR 2 BULAN DI BANJARBARU
}

\author{
Hardiono, Rahmawati \\ Poltekkes Kemenkes Banjarmasin Jurusan Kesehatan Lingkungan Banjarbaru \\ Jl. H. Mistar Cokrokusumo No. 1A Kota Banjarbaru \\ e-mail : dionhar@yahoo.com
}

\begin{abstract}
LC 50 Test of Tofu Waste Water to Tilafia (Orechromis niloticus) aged 2 months in Banjarbaru. Tofu industrial wastewater with a low $\mathrm{pH}, 0 \mathrm{mg} / \mathrm{l}$ DO and a temperature of $32^{\circ} \mathrm{C}$ when discharged without treatment into receiving water bodies will lead to the death of aquatic biota so acute toxicity tests need to be done. This study aims to determine the $\mathrm{LC}_{50}$ of the waste out in tilapia (Oreochromis niloticus). This study used an experimental method, posttest design with a control group. Samples were taken randomly in waste outlet in Banjarbaru, then toxicity tests performed with various of toxicant concentrations and exposure time at tilapia of 2 months age. Based on the initial results of toxicity tests, the lowest concentration that causes $100 \%$ dead of tilapia is $20 \%$, so that the concentration of industrial wastewater know that will be used in the acute toxicity tests are: 4, 8, 12, 16 and 20\%. Parameters wich were controlled are $\mathrm{pH}$, temperature and DO. Probit analysis using SPPS was used to determined $\mathrm{LC}_{50}$. The results showed that $\mathrm{LC}_{50}$ for exposure time: 24,48 and 72 hours are 3.80 up to $11.35 \%, 3.67$ s.d $14.30 \%$ and 3.38 up to $12.10 \%$ particularly. Correlation analysis showed the characteristics of $\mathrm{pH}$ and DO in the tofu industrial wastewater affects the $\mathrm{LC}_{50}$. Decrease of $\mathrm{DO}$ and $\mathrm{pH}, \mathrm{LC}_{50}$ would decrease. The study is expected as input to information and pollution control and waste out policy decisions in order to make local regulations maintained environmental sustainability. For further research can complement parameters Ammonia levels and turbidity in the water that affect the survival of fish, in addition to the $\mathrm{pH}, \mathrm{DO}$ and temperature of the water.
\end{abstract}

Keywords : $\mathrm{LC}_{50}$ test; tofu waste water; Tilafia (Orechromis niloticus) of 2 months aged.

Abstrak: Uji LC 50 Limbah Tahu terhadap Ikan Nila (Orechromis niloticus) Umur 2 bulan di Banjarbaru. Limbah cair industri tahu dengan kualitas pH rendah, DO $0 \mathrm{mg} / \mathrm{lt}$ dan suhu $32^{\circ} \mathrm{C}$ bila dibuang ke badan air penerima tanpa pengolahan akan mengakibatkan kematian biota aquatik sehingga perlu dilakukan uji toksisitas akut. Penelitian ini bertujuan untuk menentukan nilai $\mathrm{LC}_{50}$ dari limbah tahu terhadap ikan nila (Oreochromis niloticus). Penelitian ini menggunakan metode eksperimen rancangan post tes dengan kelompok kontrol. Sampel limbah diambil secara acak pada outlet limbah cair industri tahu di Kota Banjarbaru, kemudian dilakukan uji toksisitas dengan berbagai variasi konsentrasi toksikan dan waktu pajanan pada ikan nila umur 2 bulan. Berdasarkan hasil uji toksisitas awal konsentrasi terendah yang menyebabkan ikan nila mati $100 \%$ adalah $20 \%$, sehingga konsentrasi larutan limbah cair industri tahu yang akan digunakan dalam uji toksisitas akut adalah : 4, 8, 12, 16 dan 20\%. Parameter yang dikontrol meliputi $\mathrm{pH}$, suhu dan DO. Untuk menentukan nilai LC 50 menggunakan analisis probit menggunakan software SPPS. Hasil penelitian menunjukkan bahwa LC50 untuk waktu pajanan 24, 48 dan 72 jam masing-masing adalah 3,80 s.d 11,35\%, 3,67 s.d 14,30\% dan 3,38 s.d 12,10\%. Hasil analisis hubungan menunjukkan karakteristik pH

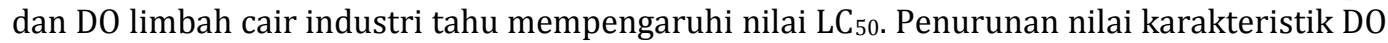
dan $\mathrm{pH}$ diikuti penurunan nilai $\mathrm{LC}_{50}$ begitu juga sebaliknya. Penelitian diharapkan memberikan informasi dan masukan untuk melakukan pengendalian pencemaran limbah tahu dan menentukan kebijakan dalam membuat peraturan daerah supaya terjaga kelestarian ling-kungan. Untuk penelitian selanjutnya dapat melengkapi parameter kadar Amoniak dan ke-keruhan pada air yang mempengaruhi kelangsungan hidup ikan, disamping $\mathrm{pH}, \mathrm{DO}$ dan suhu air.

Kata kunci : Uji LC LC $_{50}$; limbah cair tahu; ikan nila (Oreochromis niloticus) umur 2 bulan. 


\section{PENDAHULUAN}

Tahu adalah salah satu makanan tradisional yang biasa dikonsumsi setiap hari oleh orang Indonesia. Sejalan dengan keananekaragaman makanan masyarakat dalam mengkonsumsi makanan maka tahu termasuk jenis makanan yang digemari masyarakat, tidak terkecuali di Banjarbaru. Hal itu ditandai dengan banyaknya industri tahu yang didirikan masyarakat di Banjarbaru lebih kurang 10 industri rumah tangga. Proses produksi tahu menghasilkan 2 jenis limbah, limbah padat dan limbah cairan. Pada umumnya, limbah padat dimanfaatkan sebagai pakan ternak, sedangkan limbah cair dibuang langsung ke lingkungan. Limbah cair pabrik tahu ini memiliki kandungan senyawa organik yang tinggi. Tanpa proses penanganan dengan baik, limbah tahu menyebabkan dampak negatif seperti polusi air, sumber penyakit, bau tidak sedap, meningkatkan pertumbuhan nyamuk, dan menurunkan estetika lingkungan sekitar.

Sebagian besar limbah cair yang dihasilkan oleh industri pembuatan tahu adalah cairan kental yang terpisah dari gumpalan tahu yang disebut air dadih. Cairan ini mengandung kadar protein yang tinggi dan dapat segera terurai. Limbah cair ini sering dibuang secara langsung tanpa pengolahan terlebih dahulu sehingga menghasilkan bau busuk dan mencemari sungai. Sumber limbah cair lainnya berasal dari pencucian kedelai, pencucian peralatan proses, pencucian lantai dan pemasakan serta larutan bekas rendaman kedelai. Jumlah limbah cair yang dihasilkan oleh industri pembuat tahu kira-kira 15-20 l/kg bahan baku kedelai, sedangkan bahan pencemarnya kira-kira untuk TSS sebesar $30 \mathrm{~kg} / \mathrm{kg}$ bahan baku kedelai, BOD $65 \mathrm{~g} / \mathrm{kg}$ bahan baku kedelai dan COD $130 \mathrm{~g} / \mathrm{kg}$ bahan baku kedelai (Kaswinarni F, 2007).

Sebagian besar industri tahu membuang limbahnya ke badan air. Sebelum dibuang ada upaya untuk mengolah limbahnya dengan pengolahan secara fisik dengan cara diendapkan, kimia dan biologis, karena terbatasnya dana cara pengolahannyapun belum optimal sehingga kemungkinan limbah tahu yang dibuang belum memenuhi syarat efluent limbah industri makanan. Bila air sungai cukup deras dan lancar serta pengenceran cukup (daya dukung lingkungan masih baik) maka air buangan tersebut tidak menimbulkan masalah. Tetapi bila daya dukung lingkungan sudah terlampaui, maka air buangan yang banyak mengandung bahan-bahan organik akan mengalami proses penguraian oleh jasad renik dapat mencemari lingkungan. Parameter air limbah tahu yang biasanya diukur antara lain temperatur, $\mathrm{pH}$, padatan-padatan tersuspensi (TSS) dan kebutuhan oksigen (BOD dan COD). Dampak dari pembuangan limbah ke badan air akan merusak ekosistem badan air. Salah satu biota yang ada di badan air adalah ikan. Jenis ikan yang sering dikonsumsi masyarakat adalah ikan nila. Ikan nila adalah sejenis ikan konsumsi air tawar. Ikan ini diintroduk-si dari Afrika, tepatnya Afrika bagian timur, pada tahun 1969, dan kini menjadi ikan peliharaan yang populer di kolam-kolam air tawar di Indonesia. Nama ilmiahnya adalah Oreochromis niloticus, dan dalam bahasa Inggris dikenal sebagai Nile Tilapia. Hal yang perlu diperhatikan adalah kualitas air kolam pemeliharaan. Kualitas air yang kurang baik akan mengakibatkan pertumbuhan ikan menjadi lambat. Beberapa parameter yang menentukan kualitas air, diantaranya: suhu, $\mathrm{pH}$, Amoniak dan oksigen terlarut. (id.wikipedia.org/wiki/ikan_nila).

Limbah cair industri tahu yang dibuang ke badan air penerima tanpa pengolahan merupakan salah satu sumber pencemar terhadap perairan yang menyebabkan kematian biota aquatik sehingga perlu dilakukan penelitian uji toksisitas . Uji toksisitas merupakan salah satu bentuk penelitian toksikologi perairan. Uji tersebut berfungsi untuk mengetahui apakah effluent yang masuk ke badan air penerima mengandung senyawa toksik dalam konsentrasi tertentu menyebabkan kematian hewan uji yang dinyatakan dalam nilai $\mathrm{LC}_{50}$. Rumusan masalah dalam eksperimen ini adalah Berapa harga $\mathrm{LC}_{50}$ limbah tahu terhadap ikan nila (Oreochromis niloticus) di Banjarbaru? 
Penelitian ini bertujuan untuk:

1. Mengindentifikasi limbah tahu sebagai toksikan dengan parameter $\mathrm{pH}$, suhu, oksigen terlarut (DO).

2. Menganalisis konsentrasi dan efek hasil uji toksisitas untuk menentukan $\mathrm{LC}_{50}$ pada pajanan 24 jam.

3. Menganalisis kosentrasi dan efek hasil uji toksisitas untuk menentukan $\mathrm{LC}_{50}$ pada pajanan 48 jam.

4. Menganalisis kosentrasi dan efek hasil uji toksisitas untuk menentukan $\mathrm{LC}_{50}$ pada pajanan 72 jam.

Dari penelitian diharapkan ditemukan LC $_{50}$ limbah tahu (toksikan) agar dapat dipakai acuan dalam menentukan standar efluent limbah tahu di Kota Banjarbaru.
Toksikan akan menghasilkan efek negatif jika terjadi kontak dan bereaksi dengan target biota pada konsentrasi tertentu dan cukup waktu dalam memaparkan zat toksikan tersebut. Toksikan ini berupa limbah cair dari industri tahu yang mempunyai ciri-ciri fisika meliputi padatan total, padatan tersuspensi, suhu, warna, dan bau. Karakteristik kimia meliputi bahan organik, bahan anorganik dan gas. Suhu air limbah tahu berkisar 37$45^{\circ} \mathrm{C}$; kekeruhan 535-585 FTU; warna 2.225-2.250 Pt.Co; amonia 23,3-23,5 $\mathrm{mg} / 1$; $\mathrm{BOD}_{5}$ 6.000-8.000 mg/1 dan COD 7.50 0-14.000 mg/l. Selanjutnya toksikan ini akan dilakukan uji toksisitas dengan biota uji ikan nila.

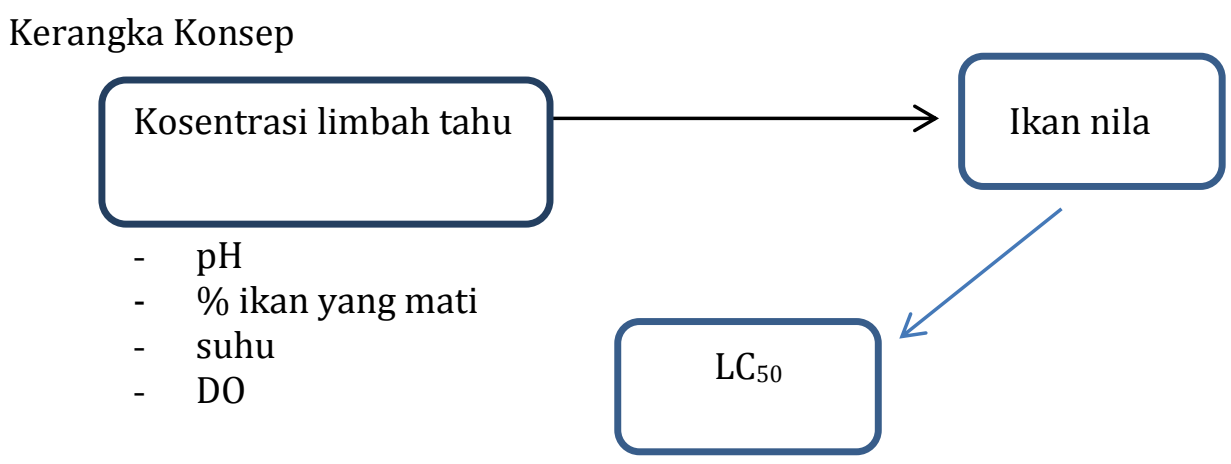

Gambar 1. Kerangka Konsep Penelitian

\section{METODE PENELITIAN}

Penelitian menggunkan metode eksperimen murni dengan rancangan postes dengan kelompok kontrol. (post test only control group design). Sebagai subyek penelitian limbah tahu (effluent) dari salah satu industri pembuatan tahu di Kota Banjarbaru, kemudian dilakukan uji toksisitas dengan cara berbagai variasi konsentrasi toksikan (limbah tahu) pada ikan nila (anakan) dengan umur yang sama pada kolam air yang telah dirancang di Laboratorium/workshop dan diikuti responnya yaitu efek kelangsungan hidup ikan tersebut.

Penelitian ini menggunakan desain Eksperimen murni, dengan gambaran sebagai berikut :

Kelompok Eksperiment:

$\mathrm{Oe} 1 \longrightarrow \mathrm{X} 1,2,3 \rightarrow \mathrm{Oe} 2$

Kelompok Kontrol :

$\mathrm{Ok} 1 \longrightarrow \mathrm{Ok} 2$ 0e1 = kelompok eksperimen pengamatan awal.

0e2 = kelompok eksperimen pengamatan akhir.

Ok1 = kelompok kontrol pengamatan awal.

Ok2 = Kelompok kontrol pengamatan akhir

$\mathrm{X}=$ perlakukan dengan replikasi 3 kali.

Variabel Independent adalah konsentrasi toksikan (limbah tahu) sedangkan variabel dependen adalah persentase ikan nila yang mati.

Penelitian ini dilakukan di Workshop Jurusan Kesehatan Lingkungan Poltekkes Kemenkes Banjarmasin, sedangkan lokasi pengambian sampe air limbah tahu dilakukan secara grab sampling pada tempat pembuangan limbah tahu di Banjarbaru. Pengambilan sampel limbah tahu dengan memperhatikan keaslian 
limbah tahu, yang memang tidak pernah dilakukan pengolahan. Pengambilan sampel dilakukan pada saat proses produksi sedang berjalan.

Populasi dalam peneitian ini yaitu limbah cair yang dikeluarkan dari industri tahu yang belum dilakukan pengolahan limbah. Sebagian dari limbah cair industri tahu di kota Banjarbaru, pengambilan dilakukan dengan cara grab sampling.

Data primer meliputi data suhu, $\mathrm{pH}$ dan oksigen terlarut dari imbah cair industri tahu berbagai konsentrasi yang telah ditentukan pada uji toksisitas, dikumpulkan datanya dengan cara pengukuran menggunakan instrument yang sesuai dengan metode pengukuran. Pengukuran dilakukan sebelum ikan nila dimasukkan ke dalam limbah cair industri tahu, dan setelah ikan nila dimasukkan kedalam limbah cair industri tahu dengan waktu 24 jam, 48 jam dan 72 jam. Jumlah ikan nila yang mati baik pada kelompok kontrol dan kelompok eksperimen dikumpulkan datanya dengan cara observasi pada waktu 24 jam, 48 jam dan 72 jam.

Data skunder tentang Industri Tahu didapat dari Dinas Perdagangan dan Industri dan Pertambangan Banjarbaru dan dari literatur yang berhubungan dengan masalah yang diteliti.

Peralatan yang digunakan dalam penelitian ini adalah rangkaian kontainer tempat untuk aklimatisasi hewan uji yang dibuat menggunakan peralatan sebagai berikut :

- Kolam ikan

- Pompa aquarium + saringan.

- Air pump (aerator) + batu aerator + slang.

- Pipa pompa

- Rangkaian kontainer uji, yang terdiri dari Toples plastik bening kapasitas 10 liter, Air pump (aerator, batu aerator dan slang) dan Rangkaian listrik (stop kontak, fitting dan kabel).

- Limbah cair dari industri tahu di Banjarbaru.

- Ikan nila dengan umur \pm 2 bulan dengan ukuran $\pm 3 \mathrm{~cm}$

- Air dari sumber PDAM, karena pH netral.
- Bahan Toksikan

Sebagai toksikan adalah limbah tahu dari industri tahu pada salah satu industri tahu yang ada di Banjarbaru kemudian dibuat variasi konsentrasi sebagai bahan toksikan yang sebelumnya dilakukan uji toksisitas.

Prosedur percobaan penelitian sebagai berikut:

1. Merpersiapkan semua alat dan bahan yang diperlukan untuk uji toksisitas

2. Memasukkan air PDAM ke dalam kolambuatan untuk tempat aklimatisasi ikan nila.

3. Memasukkan ikan nila yang sudah diseleksi menurut ukuran ke dalam kolam, biarkan selama 12 hari, untuk membiasakan ikan nila dalam lingkungan yang baru. Catat waktu mulai ikan dimasukkan ke dalam kontainer, amati dan catat jumlah ikan nila yang mati setiap 24 jam. Selama waktu aklimatisasi di tentukan prosentasi ikan yang mati. Hasil aklimatisasi menunjukkan ikan nila yang mati $<5 \%$, sehingga ikan tersebut siap digunakan sebagai biota uji.

4. Melakukan uji kontrol, dengan cara : Masukkan 10 ekor ikan nila ke dalam toples plastik yang sudah diberi air PDAM sebanyak 10 liter. Biarkan selama \pm 24 jam, kemudian amati dan catat jumlah ikan yang mati. Hasil uji kontrol menunjukkan tidak ada ikan yang mati, sehingga dapat disimpulkan kontrol yang digunakan dalam uji toksisitas dikatakan valid.

5. Melakukan uji toksisitas awal, untuk mendapatkan range finding test (konsentrasi toksikan yang akan diperlakukan dalam uji toksisitas akut), dengan cara sebagai berikut :

a. Menyiapkan larutan limbah dengan konsentrasi 10, 20, 30, 40 dan $50 \%$ di dalam toples plastik.

b. Ukur $\mathrm{pH}$, suhu dan DO larutan limbah.

c. Masukkan ke masing-masing larutan limbah ikan nila sebanyak 10 ekor dan biarkan selama \pm 72 jam, setiap 24 jam amati dan catat kematian ikan nila. 
d. Menentukan konsentrasi terkecil yang menyebabkan kematian ikan $100 \%$.

e. Menentukan range konsentrasi larutan limbah yang akan digunakan dalam uji toksisitas akut. Berdasarkan hasil uji toksisitas awal konsentrasi terendah yang menyebabkan ikan nila mati $100 \%$ adalah 20\%, sehingga konsentrasi larutan limbah cair industri tahu yang akan digunakan dalam uji toksisitas akut adalah : 4, 8, 12, 16 dan $20 \%$.

6. Melakukan uji toksisitas akut, dengan cara sebagai berikut :

a. Siapkan 6 kontainer uji, masukkan 10 liter air PDAM kedalam 1 kontainer sebagai kontrol, dan masukkan ke dalam 5 kontainer lainnya masing-masing 10 liter limbah dengan konsentrasi 4, 8, 12, 16 dan $20 \%$

b. Ukur dan catat $\mathrm{pH}$, suhu dan DO air pada masing-masing kontainer.

7. Memasukkan ke dalam masingmasing kontainer 10 ekor ikan nila. Biarkan selama 3 hari, amati dan catat jumlah ikan yang mati, $\mathrm{pH}$, suhu dan D0 setiap 24 jam.

8. Memasukkan data hasil pengamatan uji toksisitas akut kedalam tabel hasil pengamatan.

9. Mengolah dan menganalisis data hasil uji toksisitas akut untuk mendapatkan estimasi interval $\mathrm{LC}_{50}$ limbah cair industrin tahu terhadap ikan nila.

Data yang diperoleh dari hasil percobaan diolah dan dianalisis dengan menggunakan metode probit analysis, dengan langkah-langkah sebagai berikut :

1. Mentabulasi data hasil uji toksisitas akut

2. Mentransformasi skala konsentrasi limbah cair industritahu menjadi logaritmik.

3. Melakukan koreksi \% mortalitas ikan nila, jika pada control terdapat kematian ikan nila 1 s.d $20 \%$. Penetapan koreksi untuk \% mortalitas dari ikan nila digunakan rumus berikut :

Correction Mortality (\%) = $\frac{\text { Mortalitas }_{\text {obs }}-\text { Mortalitas }_{\text {control }}}{\text { Mortalitas }} \times 100 \%$
4. Mentransformasi \% mortalitas yang telah dikoreksi menjadi probit (probability units) dengan menggunakan angka transformasi probit.

5. Membuat korelasi antara log konsentrasi dengan probit mortalitas, dengan bantuan metode statistik regresi linier.

6. Menghitung log konsentrasi limbah tahu untuk probit mortalitas 1,$6 ; 5$ dan 8,4 berdasarkan persamaan garis regresi $\mathrm{Y}=\mathrm{a}+\mathrm{b} \mathrm{X}$. $(\mathrm{Y}=$ probit mortalitas ; $\mathrm{X}=\log$ konsentrasi).

7. Menghitung $\mathrm{LC}_{16} ; \mathrm{LC}_{50}$ dan $\mathrm{LC}_{84}$, dengan cara mengantilog hasil dari log konsentrasi limbah cair industri tahu

8. Menghitung nilai kemiringan garis korelasi efek harapan (Slope (S)) dengan rumus :

$\mathrm{S}=\left(\mathrm{LC}_{84} / \mathrm{LC}_{50}+\mathrm{LC}_{50} / \mathrm{LC}_{16}\right) / 2$

9. Menghitung factor $\mathrm{LC}_{50}$ (f $\mathrm{LC}_{50}$ ), dengan rumus :

f $\mathrm{LC}_{50}=\mathrm{S}\left[2,7 /\left(\mathrm{N}^{\prime}\right) 0,5\right], \mathrm{N}^{\prime}=$ jumlah biota uji dalam rentang efek $16-84 \%$

10. Menetapkan estimasi interval dari $\mathrm{LC}_{50}$ dengan formula :

- Batas bawah $=\mathrm{LC}_{50} / \mathrm{f} \mathrm{LC}_{50}$

- Batas atas $=\mathrm{LC}_{50} \times \mathrm{f} \mathrm{LC}_{50}$

11. Menyimpulkan konsentrasi limbah tahu yang dapat menyebabkan kematian ikan nila sebagai biota uji sebesar $50 \%\left(\mathrm{LC}_{50}\right)$ :

$\mathrm{LC}_{50} / \mathrm{f} \mathrm{LC}_{50} \leq \mathrm{LC}_{50} \leq \mathrm{LC}_{50} \times \mathrm{f} \mathrm{LC}_{50}$

Pengolahan dan analisis data dilakukan dengan bantuan program Ms Excel dan SPSS.

\section{HASIL PENELITIAN DAN PEMBAHASAN Gambaran Umum}

Seperti industri tahu lainnya Industri tahu di lokasi penelitian juga menghasilkan limbah padat (ampas dan limbah cair.) Sebagian besar sumber limbah cair yang dihasilkan oleh industri pembuatan tahu adalah cairan kental yang terpisah dari gumpalan tahu yang disebut dengan air dadih (whey). Cairan ini mengandung kadar protein yang tinggi dan dapat segera terurai. Limbah cair ini dibuang secara langsung tanpa pengolahan terlebih dahulu sehingga menghasilkan bau busuk dan mencemari sungai. Sumber limbah cair lainnya berasal dari pencucian kedelai, 
pencucian peralatan proses, pemasakan dan larutan bekas rendaman kedelai. Jumlah air limbah tahu yang dihasilkan oleh industri pembuatan tahu kira-kira 15-20 l/kg bahan baku kedelai. Pada industri tahu ini rata-rata perhari menghabiskan $200 \mathrm{~kg}$ kedelai sehingga jumlah limbahnya 4000 liter, sedangkan beban pencemarannya kira-kira sebesar $30 \mathrm{~kg}$ Total Suspended Solids (TSS)/kg bahan baku kedelai, jadi dalam $200 \mathrm{~kg}$ bahan kedelai maka TSS berjumlah $600 \mathrm{~kg}$ TSS, Biologycal Oxygen Demand (BOD) $13 \mathrm{~kg} /$ $200 \mathrm{~kg}$ bahan baku kedelai dan Chemical Oxygen Demand (COD) $26 \mathrm{~kg} / 200 \mathrm{~kg}$ bahan baku kedelai. Pada penelitian ini parameter yang diukur terdiri dari $\mathrm{pH}$, Suhu dan DO dengan hasil $\mathrm{pH} 4$, suhu $32^{\circ} \mathrm{C}$ dan DO $0 \mathrm{mgr} / \mathrm{lt}$ Bisa dibayangkan bila limbah cair tersebut dibuang langsung ke badan air maka akan terjadi pencemaran air dan akan berdampak pada kehidupan biota di sungai tersebut. Hal yang perlu diperhatikan adalah kualitas air kolam pemeliharaan. Kualitas air yang kurang baik akan mengakibatkan pertumbuhan ikan menjadi lambat.

Beberapa parameter yang menentukan kualitas air, diantaranya: suhu, $\mathrm{pH}$, Amoniak dan oksigen terlarut. Ikan nila berkerabat dekat dengan mujair (Oreochromis mossambicus) dan sebagai- mana kerabatnya itu pula, ikan nila memiliki potensi sebagai ikan yang invasif apabila terlepas ke badan-badan air alami. Genus Oreochromis memiliki kemampuan adaptasi yang tinggi dan toleransi terhadap kualitas air pada kisaran yang lebar. Anggota-anggota genus ini dapat hidup dalam kondisi lingkungan yang ekstrem sekalipun, karena sering ditemukan hidup normal pada habitat-habitat di mana jenis ikan air tawar lainnya tak dapat hidup. Kualitas limbah dengan $\mathrm{pH}$ sangat asam dan DO yang tidak ada sama sekali (nol) maka kelangsungan hidup ikan nila akan terancam. Kualias limbah tahu yang tidak diolah mengakibatkan pencemaran badan air dan tentunya ekosistem perairan dan biota akan terancam punah.

\section{Hasil Uji Toksisitas Limbah Tahu pada Ikan Nila.}

Pengujian toksisitas limbah pabrik tahu terhadap ikan nila dilaksanakan di Workshop Jurusan Kesehatan Lingkungan. Pengujian dilakukan terhadap 10 ekor ikan nila pada masing-masing konsentrasi limbah tahu dengan waktu pajanan 24, 48 dan 72 jam. Hasil pengamatan proporsi ikan nila yang mati untuk setiap perlakuan kosentrasi limbah tahu dan waktu pajanan dapat dilihat pada tabel 1 sebagai berikut :

Tabel 1. Hasil Pengamatan Uji Toksisitas Limbah Tahu Terhadap Ikan Nila

\begin{tabular}{cccccc}
\hline $\begin{array}{c}\text { Waktu } \\
\text { Pajanan }\end{array}$ & $\begin{array}{c}\text { \% Kosentrasi } \\
\text { Limbah }\end{array}$ & \multicolumn{4}{c}{ \% Kematian Ikan Nila } \\
\hline (1) & $(2)$ & $(3)$ & $(4)$ & 3 & rata-rata \\
\hline 24 jam & 0 & 0 & 0 & 0 & $(5)$ \\
& 4 & 0 & 0 & 0 & 0 \\
& 8 & 40 & 30 & 40 & 0 \\
& 12 & 50 & 30 & 60 & 46,7 \\
& 16 & 90 & 70 & 80 & 80 \\
48 jam & 20 & 100 & 100 & 100 & 100 \\
& 0 & 10 & 0 & 0 & 3,3 \\
& 4 & 30 & 10 & 20 & 20,0 \\
& 8 & 50 & 40 & 40 & 43,3 \\
& 12 & 90 & 90 & 80 & 86,7 \\
& 16 & 100 & 100 & 90 & 96,7 \\
& 20 & 100 & 100 & 100 & 100 \\
\hline
\end{tabular}




\begin{tabular}{cccccc}
\hline$(1)$ & $(2)$ & $(3)$ & $(4)$ & $(5)$ & $(6)$ \\
\hline 72 jam & 0 & 10 & 0 & 0 & 3,3 \\
& 4 & 30 & 20 & 20 & 23,3 \\
& 8 & 70 & 40 & 60 & 56,7 \\
& 12 & 100 & 80 & 90 & 90,0 \\
& 16 & 100 & 100 & 100 & 100 \\
& 20 & 100 & 100 & 100 & 100 \\
\hline
\end{tabular}

Dari tabel 1 menunjukkan konsentrasi limbah tahu berbanding lurus dengan persentase kematian ikan nila untuk setiap waktu pajanan. Semakin tinggi kosentrasi limbah tahu, semakin tinggi prosentase kematian ikan nila. Demikian juga halnya dengan waktu pajanan, semakin lama waktu pajanan semakin tinggi prosentase kematian ikan nila. Pada kontrol baik 24 jam, 48 jam dan 72 jam pajanan rata-rata ikan yang mati $0 \%$. Kemudian semakin meningkat konsentrasi limbah tahu semakin besar proporsi ikan yang mati. Pada konsentrai 20\% waktu pajanan 24 jam, 48 jam dan 72 jam proporsi ikan yang mati $100 \%$ bahkan pada pajanan 72 jam pada konsentrasi 16 $\%$ juga ikan yang mati $100 \%$.

Kematian ikan nila dan faktor kualitas air limbah tahu

Kondisi air limbah tahu meliputi oksigen terlarut (DO), pH dan suhu diduga menentukan kematian ikan nila yang terpajan dengan limbah tahu.

Hasil pengukuran oksigen terlarut pada air limbah tahu dapat dilihat pada tabel 2 berikut ini.

Tabel 2. Hasil Pengamatan Oksigen Terlarut (DO) Air Limbah Tahu pada Uji Toksisitas Limbah Tahu Terhadap Ikan Nila.

\begin{tabular}{cccccc}
\hline Waktu & \% Kosentrasi & \multicolumn{4}{c}{ D0 (mg/liter) } \\
\cline { 2 - 5 } Pajanan & limbah & 1 & 2 & 3 & rata-rata \\
\hline 24 jam & 0 & 5.8 & 5.5 & 4,9 & 5,4 \\
& 4 & 3,8 & 4,5 & 5,1 & 4,5 \\
& 8 & 3,1 & 4,9 & 4,4 & 4,1 \\
& 12 & 2,6 & 3,8 & 2,1 & 2,8 \\
& 16 & 0 & 0 & 0 & 0 \\
48 jam & 20 & 0 & 0 & 0 & 0 \\
& 0 & 6,4 & 5,9 & 5,7 & 6,0 \\
& 4 & 5,5 & 5,6 & 4,4 & 5,2 \\
& 8 & 3,8 & 3,2 & 3,2 & 3,4 \\
& 12 & 3,4 & 3,8 & 2,5 & 3,2 \\
72 jam & 16 & 0 & 0 & 1,4 & 0,5 \\
& 20 & 0 & 0 & 0 & 0 \\
& 0 & 7,9 & 5,5 & 4,7 & 6,0 \\
& 4 & 5,9 & 6,2 & 4,3 & 5,5 \\
& 12 & 6,2 & 5,5 & 5,6 & 5,8 \\
& 16 & 7,2 & 3,4 & 7,5 & 6,0 \\
& 20 & 0 & 0 & 0 & 0 \\
& 0 & 0 & 0 & 0 & 0 \\
\hline
\end{tabular}

Tabel 2 menunjukkan rata-rata oksigen terlarut tertinggi terdapat pada air tanpa limbah tahu, yaitu 6,0 $\mathrm{mg} / \mathrm{liter}$, sedangkan oksigen terlarut (DO) sudah tidak ditemukan (0 mgr/lt) pada air limbah dengan konsentrasi $20 \%$. Secara umum semakin tinggi kosentrasi limbah tahu semakin rendah oksigen terlarut pada air limbah, bahkan pada pajanan 72 jam dengan 16\% toksikan dari limbah tahu DO juga $0 \mathrm{mgr} / \mathrm{lt}$. Oksigen diperlukan ikan untuk kelangsungan hidup ikan nila, 
maka dengan banyaknya limbah dan waktu pajanan semakin meningkat maka oksigen terlarut menipis dan akhirnya ikan banyak yang mati.
Hasil pengukuran pH air limbah tahu ditunjukkan pada tabel 3 berikut ini :

Tabel 3. Hasil Pengukuran Derajat Keasaman (pH) Air Limbah Tahu pada Uji Toksisitas Limbah Tahu terhadap Ikan Nila

\begin{tabular}{cccccc}
\hline Waktu & \% Kosentrasi & \multicolumn{4}{c}{ pH air limbah tahu } \\
\cline { 2 - 5 } Pajanan & limbah & 1 & 2 & 3 & rata-rata \\
\hline 24 jam & 0 & 7,0 & 7,0 & 7,0 & 7,0 \\
& 4 & 6,5 & 6,0 & 6.5 & 6,3 \\
& 8 & 6,0 & 6,0 & 6,0 & 6,0 \\
& 12 & 6.5 & 7,0 & 6,0 & 6,5 \\
& 16 & 6,0 & 5,0 & 4,0 & 5,0 \\
48 jam & 20 & 4,0 & 4,0 & 5,0 & 4,3 \\
& 0 & 7,0 & 7,0 & 7,0 & 7,0 \\
& 4 & 7,0 & 6,0 & 7,0 & 6,3 \\
& 8 & 7,0 & 7,0 & 6,0 & 6,3 \\
& 12 & 7,0 & 7,0 & 6,0 & 6,3 \\
72 jam & 16 & 7,0 & 7,0 & 8,0 & 7,3 \\
& 20 & 5,0 & 4,0 & 5,0 & 4,3 \\
\hline 0 & 7,0 & 7,0 & 8,0 & 7,0 \\
& 4 & 7,0 & 7,0 & 7,0 & 7,0 \\
& 8 & 7,0 & 8,0 & 7,0 & 7,6 \\
& 12 & 7,0 & 7,0 & 8,0 & 7,6 \\
& 16 & 7,0 & 8,0 & 8,0 & 7,6 \\
& 20 & 5,0 & 5,0 & 6,0 & 5,3 \\
\hline
\end{tabular}

Tabel 3 menunjukkan $\mathrm{pH}$ air limbah tahu berkisar antara 4,3 s.d 7,0. Derajat keasaman terendah terdapat pada air limbah tahu dengan konsentrasi $20 \%$. Derajat keasaman pada air limbah dengan waktu pajanan 24 jam umumnya hampir sama dengan derajat keasaman air limbah dengan waktu pajanan 48 jam. Kenaikan
$\mathrm{pH}$ terjadi setelah waktu pajanan 72 jam. Hal tersebut dimungkinkan adanya proses dekomposisi dari limbah tahu yang mengandung protein sehingga semakin lama pH semakin netral.

Hasil pengukuran suhu air limbah tahu dapat dilihat pada tabel 4 berikut ini:

Tabel 4. Hasil Pengukuran Suhu Air Limbah Tahu pada Uji Toksisitas Limbah Tahu terhadap Ikan Nila

\begin{tabular}{cccccc}
\hline Waktu & \% Kosentrasi & \multicolumn{4}{c}{ Suhu Limbah Tahu $\left({ }^{\circ} \mathrm{C}\right)$} \\
\cline { 2 - 6 } Pajanan & limbah & 1 & 2 & 3 & rata-rata \\
\hline (1) & $(2)$ & $(3)$ & $(4)$ & $(5)$ & $(6)$ \\
\hline 24 jam & 0 & 28 & 29 & 28 & 28,3 \\
& 4 & 28 & 30 & 28 & 28,6 \\
& 8 & 28 & 29 & 28 & 28,3 \\
& 12 & 30 & 29 & 28 & 29,0 \\
& 16 & 28 & 30 & 28 & 28,6 \\
& 20 & 30 & 28 & 27 & 28,3 \\
\hline
\end{tabular}




\begin{tabular}{cccccc}
\hline$(1)$ & $(2)$ & $(3)$ & $(4)$ & $(5)$ & $(6)$ \\
\hline 48 jam & 0 & 28 & 27 & 27 & 27,3 \\
& 4 & 27 & 28 & 28 & 27,6 \\
& 8 & 27 & 28 & 29 & 28,0 \\
& 12 & 28 & 29 & 28 & 28,3 \\
& 16 & 28 & 28 & 27 & 27,6 \\
72 jam & 20 & 28 & 28 & 28 & 28,0 \\
& 0 & 28 & 28 & 28 & 28,0 \\
& 4 & 29 & 29 & 29 & 29,0 \\
& 8 & 28 & 29 & 29 & 28,6 \\
& 12 & 29 & 29 & 29 & 29,0 \\
& 16 & 27 & 27 & 27 & 27,0 \\
& 20 & 28 & 28 & 28 & 28,0 \\
\hline
\end{tabular}

Tabel 4 menunjukkan suhu air limbah tahu berbagai konsentrasi dan waktu pajanan tidak terlalu berbeda. Suhu air limbah berkisar antara $27{ }^{\circ} \mathrm{C}$ s.d $29^{\circ} \mathrm{C}$. Di samping $\mathrm{pH}$, DO dan suhu ada beberapa parameter air limbah yang mempengaruhi kelangsungan hidup ikan nilai : Amonia dan Kekeruhan, BOD dan COD (Yuniarti Sani, Elly, 2006). Amonia merupakan bentuk utama ekskresi nitrogen dari organisme akuatik. Sumber utama amonia $\left(\mathrm{NH}_{3}\right)$ adalah bahan organik dalam bentuk sisa pakan, kotoran ikan maupun dalam bentuk plankton dari bahan organik tersuspensi. Pembusukan bahan organik, terutama yang banyak mengandung protein, menghasilkan ammonium $\left(\mathrm{NH}_{4}{ }^{+}\right)$dan $\mathrm{NH}_{3}$. Bila proses lanjut dari pembusukan (nitrifikasi) tidak berjalan lancar maka dapat terjadi penumpukan NH3 sampai pada konsentrasi yang membahayakan bagi ikan. Kekeruhan air yang disebabkan oleh pelumpuran di dasar kolam juga akan memperlambat pertumbuhan ikan. Lain halnya bila kekeruhan air disebabkan oleh adanya plankton; air yang kaya plankton dapat berwarna hijau kekuningan dan hijau kecoklatan karena banyak mengandung diatom. Plankton ini baik sebagai makanan ikan nila, sedangkan plankton biru kurang baik. Tingkat kecerahan air karena plankton harus dikendalikan.

(http://id.wikipedia.org/wiki/Ikan_nila). Analisis Konsentrasi Efek Limbah Tahu terhadap Ikan Nila.

Analisis kosentrasi efek dimaksudkan untuk menentukan kosentrasi limbah tahu yang dapat mengakibatkan kematian $50 \%$ dari ikan nila sebagai biota uji ( $\left.\mathrm{LC}_{50}\right)$. Metode yang digunakan untuk menganalisis konsentrasi efek adalah Probit Analysis.

Hasil transformasi konsentarasi limbah tahu dan \% mortalitas ikan nila ditunjukkan pada tabel 5 berikut :

Tabel 5. Hasil Transformasi Konsentrasi Limbah Tahu dan Prosentase Kematian Ikan Nila dengan Waktu Pajanan 24 jam

\begin{tabular}{cccc}
\hline Konsentrasi (\%) & Log Konsentrasi & \% mortalitas & Probit mortalitas \\
\hline 0 & 0 & 0 & 0 \\
4 & 0,602 & 0 & 0 \\
8 & 0,903 & 36,7 & 4,67 \\
12 & 1,079 & 46,7 & 4,92 \\
16 & 1,204 & 80,0 & 5,84 \\
20 & 1,301 & 100 & 8.09 \\
\hline
\end{tabular}

Berdasarkan tabel 45, dibuat korelasi antara log konsentrasi dengan probit mortalitas seperti ditunjukkan pada gambar 2 berikut ini : 


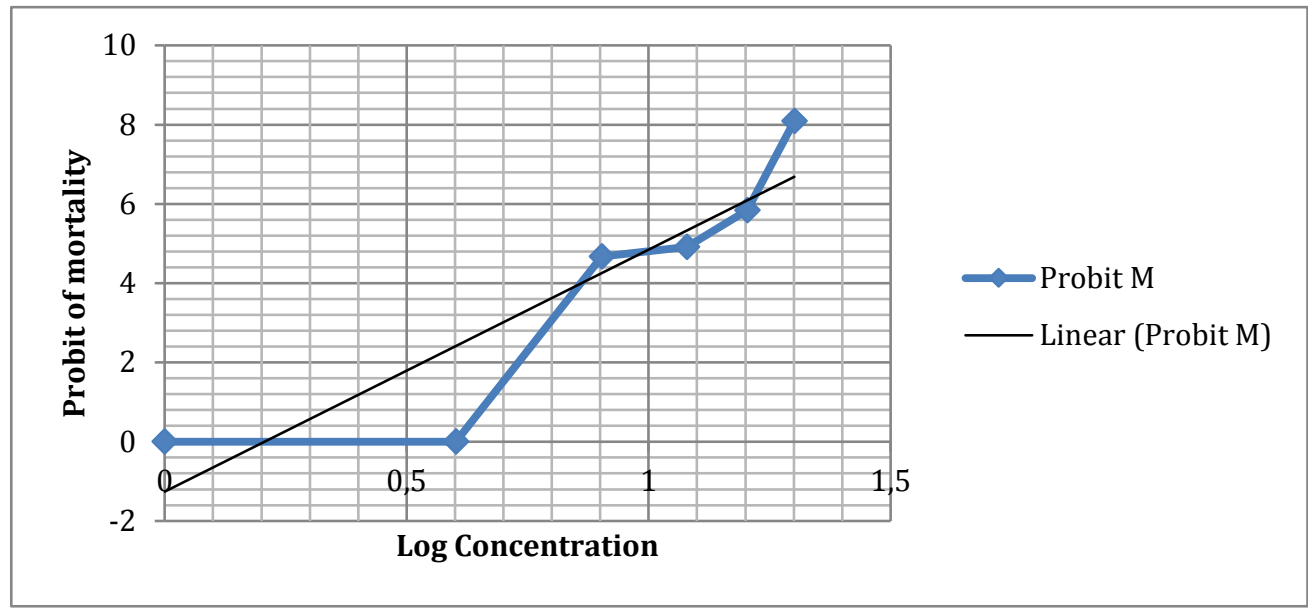

Gambar 2. Korelasi log Konsentrasi Limbah Tahu dengan Probit Mortalitas Ikan Nila dengan Waktu Pajanan 24 Jam

Estimasi $\mathrm{LC}_{50}$ limbah tahu terhadap ikan nila menggunakan analisis regresi linear. Hasil analisis regresi linear didapatkan persamaan garis sebagai berikut $\mathrm{y}=6,117 \mathrm{x}$, dimana $\mathrm{y}=$ probit mortalitas dan $\mathrm{x}=\log$ konsentrasi limbah tahu. Dengan menggunakan persamaan garis regresi tersebut dapat ditentukan nilai $\mathrm{LC}_{16}, \mathrm{LC}_{50}$ dan $\mathrm{LC}_{84}$ limbah tahu.
Selanjutnya hasil perhitungan tersebut digunakan untuk menentukan nilai Slope (S) dan $\mathrm{fLC}_{50}$, sebagai dasar untuk menen-tukan estimasi interval dari $\mathrm{LC}_{50}$ limbah tahu terhadap ikan nila.

Hasil perhitungan toksisitas limbah tahu terhadap ikan nila disajikan pada tabel 4.6 berikut ini :

Tabel 6. Hasil Perhitungan Toksisitas Limbah Tahu terhadap Ikan dengan Waktu Pajanan $24 \mathrm{Jam}$

\begin{tabular}{ccccccc}
\hline $\begin{array}{l}\text { Nilai } \\
\mathrm{LC}_{16}\end{array}$ & $\begin{array}{c}\text { Nilai } \\
\mathrm{LC}_{50}\end{array}$ & $\begin{array}{c}\text { Nilai } \\
\mathrm{LC}_{84}\end{array}$ & Slope $(\mathrm{S})$ & $\mathrm{fLC}_{50}$ & $\begin{array}{c}\text { Batas } \\
\text { Bawah LC }\end{array}$ & $\begin{array}{c}\text { Batas Atas } \\
\mathrm{LC}_{50}\end{array}$ \\
\hline 1,83 & 6,57 & 23.62 & 3.6 & 1,70 & 3,80 & 11,35 \\
\hline
\end{tabular}

Berdasarkan hasil perhitungan toksisitas limbah tahu terhadap ikan nila dapat ditentukan kosentrasi limbah tahu yang mengakibat kematian $50 \%$ ikan nila ( $\mathrm{LC}_{50}$ ) adalah :3,80 s.d 11,35 \%.
Hasil transformasi konsentarasi limbah tahu dan \% mortalitas ikan nila ditunjukkan pada tabel 7 berikut:

Tabel 7. Hasil Transformasi Konsentrasi Limbah Tahu dan Prosentase Kematian Ikan Nila dengan Waktu Pajanan 48 jam

\begin{tabular}{ccccc}
\hline $\begin{array}{c}\text { Konsentrasi } \\
(\%)\end{array}$ & Log Konsentrasi & \% mortalitas & $\begin{array}{c}\text { Koreksi } \\
\text { \% Mortalitas }\end{array}$ & $\begin{array}{c}\text { Probit } \\
\text { mortalitas }\end{array}$ \\
\hline 0 & 0 & 3.3 & 0 & 0 \\
4 & 0,602 & 20 & 17,5 & 4,08 \\
8 & 0,903 & 43,3 & 41,2 & 4,77 \\
12 & 1,079 & 86,7 & 86,6 & 6,13 \\
16 & 1,204 & 96,7 & 96,9 & 6,88 \\
20 & 1,301 & 100,0 & 100 & 8.09 \\
\hline
\end{tabular}


Berdasarkan tabel 7, dibuat korelasi antara log konsentrasi limbah tahu

dengan probit mortalitas ikan nila seperti ditunjukkan pada gambar 4.2 berikut ini :

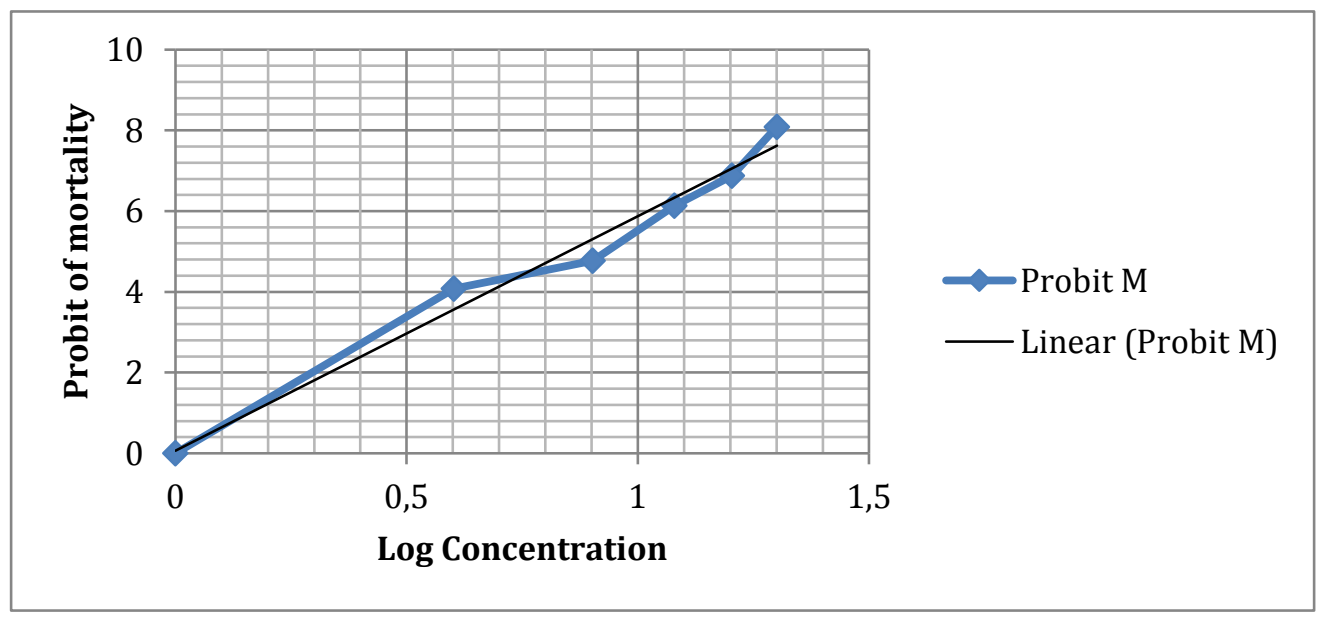

Gambar 3. Korelasi log Konsentrasi Limbah Tahu dengan Probit Mortalitas Ikan Nila dengan Waktu Pajanan 48 Jam

Untuk mengestimasi $\mathrm{LC}_{50}$ limbah tahu terhadap ikan nila digunakan analisis regresi linear. Hasil analisis regresi linear didapatkan persamaan garis sebagai berikut : $\mathrm{y}=5,815 \mathrm{x}$, dimana $\mathrm{y}=$ probit mortalitas dan $\mathrm{x}=\log$ konsentrasi limbah tahu.

Dengan menggunakan persamaan garis regresi tersebut dapat ditentukan nilai $\mathrm{LC}_{16}, \mathrm{LC}_{50}$ dan $\mathrm{LC}_{84}$ limbah tahu. Selanjutnya hasil perhitungan tersebut digunakan untuk menentukan nilai Slope (S) dan $\mathrm{fLC}_{50}$, sebagai dasar untuk menentukan estimasi interval dari $\mathrm{LC}_{50}$ limbah tahu terhadap ikan nila.

Hasil perhitungan toksisitas limbah tahu terhadap ikan nila disajikan pada tabel 8 berikut ini :

Tabel 8. Hasil Perhitungan Toksisitas Limbah Tahu terhadap Ikan Nila dengan Waktu Pajanan 48 Jam

\begin{tabular}{ccccccc}
\hline $\begin{array}{c}\text { Nilai } \\
\mathrm{LC}_{16}\end{array}$ & $\begin{array}{c}\text { Nilai } \\
\mathrm{LC}_{50}\end{array}$ & $\begin{array}{l}\text { Nilai } \\
\mathrm{LC}_{84}\end{array}$ & Slope (S) & $\mathrm{fLC}_{50}$ & $\begin{array}{c}\text { Batas Bawah } \\
\mathrm{LC}_{50}\end{array}$ & $\begin{array}{c}\text { Batas Atas } \\
\mathrm{LC}_{50}\end{array}$ \\
\hline 1,9 & 7,2 & 27,8 & 3,84 & 2,0 & 3,67 & 14,30 \\
\hline
\end{tabular}

Berdasarkan hasil perhitungan toksisitas limbah tahu terhadap ikan nila dapat ditentukan kosentrasi limbah tahu yang mengakibat kematian 50\% ikan nila
(LC50) adalah 3,67 s.d 14,30\%. Hasil transformasi konsentarasi limbah tahu dan \% mortalitas ikan nila ditunjukkan pada tabel 9 berikut :

Tabel 9. Hasil Transformasi Konsentrasi Limbah Tahu dan Prosentase Kematian Ikan Nila Waktu Pajanan 72 jam

\begin{tabular}{ccccc}
\hline $\begin{array}{c}\text { Konsentrasi } \\
(\%)\end{array}$ & $\begin{array}{c}\text { Log } \\
\text { Konsentrasi }\end{array}$ & $\begin{array}{c}\% \\
\text { mortalitas }\end{array}$ & $\begin{array}{c}\text { Koreksi } \\
\text { \% Mortalitas }\end{array}$ & $\begin{array}{c}\text { Probit } \\
\text { mortalitas }\end{array}$ \\
\hline 0 & 0 & 3 & 0 & 0 \\
4 & 0,602 & 23 & 20,6 & 4,19 \\
8 & 0,903 & 57 & 55,7 & 5,15 \\
12 & 1,079 & 90 & 89,7 & 6,28 \\
16 & 1,204 & 100 & 100 & 8.09 \\
20 & 1,301 & 100 & 100 & 8,09 \\
\hline
\end{tabular}


Berdasarkan tabel 9, dibuat korelasi antara log konsentrasi limbah tahu dengan probit mortalitas ikan nila seperti ditunjukkan pada gambar 4 berikut ini :

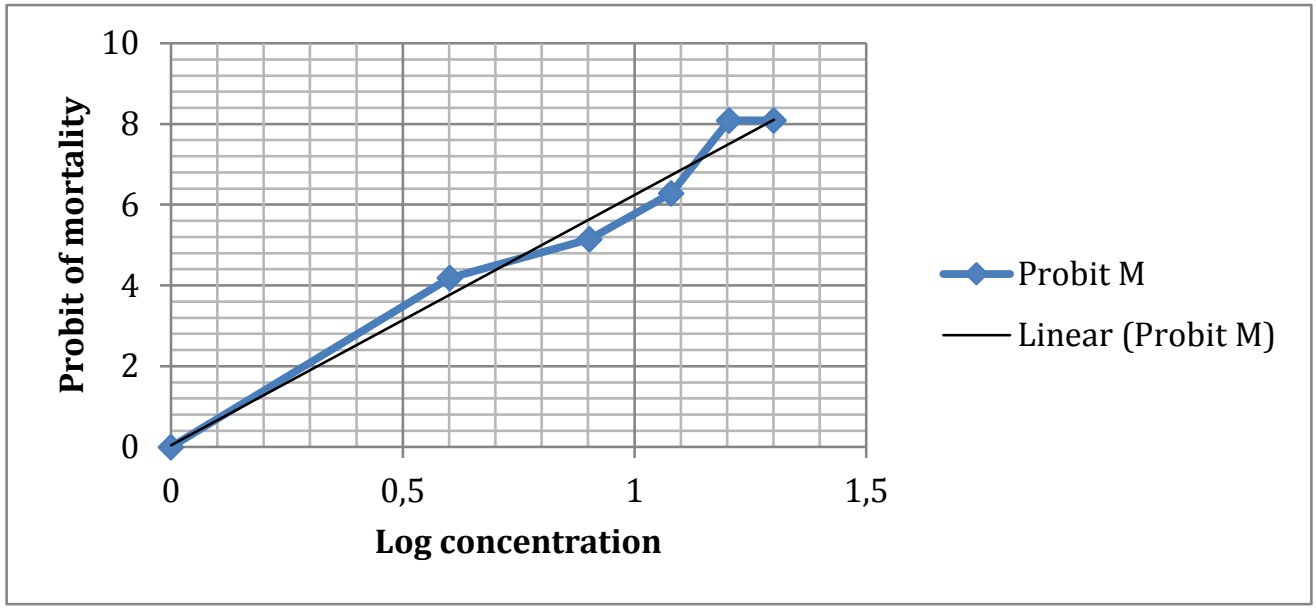

Gambar 4. Korelasi log Konsentrasi Limbah Tahu dengan Probit Mortalitas Ikan Nila dengan Waktu Pajanan 72 Jam

Untuk mengestimasi $\mathrm{LC}_{50}$ limbah tahu terhadap ikan nila digunakan analisis regresi linear. Hasil analisis regresi linear didapatkan persamaan garis sebagai berikut : $y=6,206 x$, dimana $y=$ probit mortalitas dan $\mathrm{x}=\log$ konsentrasi limbah tahu.

Dengan menggunakan persamaan garis regresi tersebut dapat ditentukan nilai $\mathrm{LC}_{16}, \mathrm{LC}_{50}$ dan $\mathrm{LC}_{84}$ limbah tahu.
Selanjutnya hasil perhitungan tersebut digunakan untuk menentukan nilai Slope (S) dan $\mathrm{fLC}_{50}$, sebagai dasar untuk menentukan estimasi interval dari $\mathrm{LC}_{50}$ limbah tahu terhadap ikan nila.

Hasil perhitungan toksisitas limbah tahu terhadap ikan nila disajikan pada tabel 4.10 berikut ini,

Tabel 10. Hasil Perhitungan Toksisitas Limbah Tahu terhadap Ikan Nila dengan Waktu Pajanan 72 Jam

\begin{tabular}{ccccccc}
\hline $\begin{array}{l}\text { Nilai } \\
\mathrm{LC}_{16}\end{array}$ & $\begin{array}{c}\text { Nilai } \\
\mathrm{LC}_{50}\end{array}$ & $\begin{array}{c}\text { Nilai } \\
\mathrm{LC}_{84}\end{array}$ & Slope (S) & $\mathrm{fLC}_{50}$ & $\begin{array}{c}\text { Batas Bawah } \\
\mathrm{LC}_{50}\end{array}$ & $\begin{array}{c}\text { Batas Atas } \\
\mathrm{LC}_{50}\end{array}$ \\
\hline 1,81 & 6,39 & 22,57 & 3,53 & 1,9 & 3,38 & 12,10 \\
\hline
\end{tabular}

Berdasarkan hasil perhitungan toksisitas limbah tahu terhadap ikan nila dapat ditentukan kosentrasi limbah tahu yang mengakibat kematian $50 \%$ ikan nila ( $\mathrm{LC}_{50}$ ) adalah :3,38 s.d 12,10\%.

\section{KESIMPULAN DAN SARAN Kesimpulan}

Berdasarkan hasil dan pembahasan yang didapatkan, penelitian mengenai uji toksisitas akut $\left(\mathrm{LC}_{50}\right)$ limbah cair industri tahu "Banjarbaru" terhadap ikan nila (Oreochromios niloticus.), dapat diambil beberapa kesimpulan sebagai berikut: Karakteristik Limbah tahu mempunyai parameter, $\mathrm{pH} 4$, suhu $32^{\circ} \mathrm{C}$ dan $\mathrm{DO}=0$ $\mathrm{mgr} / \mathrm{lt}$

1. Nilai $\mathrm{LC}_{50}$ waktu pajanan 24 jam konsentrasi limbah tahu yang mengakibat kematian ${ }_{50} \%$ ikan nila $\left(\mathrm{LC}_{50}\right)$ adalah : 3,80 s.d $11,35 \%$.

2. Nilai $\mathrm{LC}_{50}$ waktu pajanan 48 jam konsentrasi limbah tahu yang mengakibat kematian ${ }_{50} \%$ ikan nila $\left(\mathrm{LC}_{50}\right)$ adalah : 3,67 s.d $14,30 \%$.

3. Nilai $\mathrm{LC}_{50}$ waktu pajanan 72 jam konsentrasi limbah tahu yang mengakibat kematian ${ }_{50} \%$ ikan nila $\left(\mathrm{LC}_{50}\right)$ adalah : 3,38 s.d $12,10 \%$. 


\section{Saran.}

1. Pada industri tahu diharapkan tidak membuang limbahnya langsung ke badan air tetapi perlu pengolahan terlebih dahulu misalnya dengan cara pengendapan dan pengenceran.

2. Pada pihak Pemerintah Kota (Dinas Perindustrian, Perdagangan dan Pertambangan Banjarbaru) diharapkan dapat menggunakan hasil penelitian ini sebagai informasi dan masukan untuk melakukan pengandalian pencemaran Lingkungan (limbah industri tahu) dan menentukan kebijakan dalam membuat Peraturan daerah untuk kelestarian lingkungan hidup.

3. Untuk penelitian selanjutnya dapat melengkapi parameter lingkungan berupa pengukuran kadar Amoniak dan kekeruhan pada air yang mempengaruhi kelangsungan hidup ikan, di samping $\mathrm{pH}, \mathrm{DO}$ dan suhu air.

\section{DAFTAR PUSTAKA}

Darmono, Lingkungan Hidup dan Pencemaran Hubungannya dengan Toksikologi Senyawa Logam, Jakarta : UI Press, 2006.

EPA.Methods for Measuring The Acute Toxicity of Effluents and Receiving Water to Fresh Organisms 14th edition. Weber, C. I, Editor, USEPA: Ohio., 1992
Husni, Hayatul dan Esmiralda Uji Toksisitas Akut Limbah Cair Industri Tahu Terhadap Ikan Mas (Cyprinus Caprio Lin), Padang : Universitas Andalas Jurusan TL, 2006

Kasniwarwarni, Febria, Kajian Teknis Pengolahan Limbah Padat dan Cair Industri Tahu, Thesis Semarang : Pascasarjana Ilmu Lingkungan , 2007.

Mangkoedihardjo, Sarwoko dan Ganjar Samudro, Ekotoksikologi Teknosfer, Surabaya : Guna Widya, 2009.

Nazir Muhammad, Metode Penelitian, Jakarta : PT Ghalia Indonesia, 1985.

Soemirat, Yuli, Toksikologi Lingkungan : : Yogjakarta: UGM Press , 2003.

Sudjana, Desain dan Analisi Eksperiment, Bandung : PT Tarsito, 1994.

Widyastuti, Palupi (alih bahasa), editor : Monica Ester, Bahaya Bahan Kimia Pada Kesehatan Manusia dan Lingkungan (WHO): Jakarta : EGC, 2005.

Yuniarti Sani, Elly, Pengolahan Air Limbah Tahu Menggunakan Reaktor Anaerob bersekat dan Aerob, Thesis, Pascasarjana Ilmu Lingkungan Undip Semarang : 2006 http://id.wikipedia.org/wiki/Ikan nila. Bahasa Indonesia, Ikan Nila, internet, akses 10 Desember 2011. 